\title{
Novel Marine Compounds: Anticancer or Genotoxic?
}

\author{
Jamal M. Arif,* Amal A. Al-Hazzani, Muhammed Kunhi, and Fahad Al-Khodairy \\ Biological and Medical Research, King Faisal Specialist Hospital and Research Center, \\ PO Box 3354, MBC \#03, Riyadh 11211, Saudi Arabia
}

Received 27 July 2003; revised 4 December 2003; accepted 4 December 2003

\begin{abstract}
In the past several decades, marine organisms have generously gifted to the pharmaceutical industries numerous naturally bioactive compounds with antiviral, antibacterial, antimalarial, anti-inflammatory, antioxidant, and anticancer potentials. But till date only few anticancer drugs (cytarabine, vidarabine) have been commercially developed from marine compounds while several others are currently in different clinical trials. Majority of these compounds were tested in the tumor xenograft models, however, lack of anticancer potential data in the chemical- and/or oncogene-induced pre-initiation animal carcinogenesis models might have cost some of the marine anticancer compounds an early exit from the clinical trials. This review critically discusses importance of preclinical evaluation, failure of human clinical trials with certain potential anticancer agents, the screening tests used, and choice of biomarkers.
\end{abstract}

\section{INTRODUCTION}

Marine organisms provided numerous novel compounds with sensational multiple pharmacological properties $[1,2,3,4,5,6,7]$. During the past 20 years, thousands of novel compounds and their metabolites with diverse biological activities ranging from antiviral to anticancer have been isolated from various marine sources $[3,4,5,6]$. The marine pharmacy currently holds more than 35000 marine-derived biological samples, with approximately 150 compounds to be cytotoxic against the tumor cells [3]. Recent reviews further suggest that approximately 35 compounds have a known mechanism(s) of action for their antitumor effect while 124 marine compounds yet to be studied for their detailed mechanism of antitumor activity $[2,4,7]$. Out of 35 antitumor compounds, at least a dozen of them are currently in various phases of human clinical trials for treatment of different cancers [4]. Some of the prominent anticancer compounds in clinical trials include ecteinascidin (Yondelis), bryostatin-1, squalamine, aplidin, dolastatin-10, ILX651, and KRN7000 ( $\alpha$-galactosylceramide) (Table 1) [4].

\section{PRECLINICAL EVALUATIONS AND CLINICAL TRIALS}

Most of the compounds were tested in vitro by highthroughput cost-effective screening assays using exclusively cancer cell lines derived from human and rodent sources $[2,7]$. Based on the in vitro antitumor activity, several of these compounds were tested for their therapeutic efficacy in the tumor xenograft models in animals. However, toxicity studies in animal models are limited to only few anticancer compounds (Table 1$)[8,9$,
$10,11,12,13,14,15,16,17]$. Review of the published literature on the genotoxicity and anticancer potentials of these compounds in vivo revealed that very few compounds have gone through the preclinical evaluations in the chemical- or oncogene-induced pre-initiation animal carcinogenesis models $[4,8,18]$. Interestingly, cytarabine (Cytostar-U), isolated from the Caribbean sponge (Cryptotheca crypta) and currently being used in routine treatment of patients with leukemia and lymphoma [8], seems to be one of the very few marine anticancer drugs studied in long-term pre-initation cancer model in F344 rats for its anticancer efficacy [19]. It showed anticancer potential by inhibiting the promoting effect of mitomycin $\mathrm{C}$ in N-butyl-N-(4-hydroxybutyl)nitrosamine (BBN)-induced bladder carcinogenesis. Recent studies further showed that another marine compound, KRN7000, was found to be effective against methylcholanthrene (MC)-induced fibrosarcomas, mammary carcinomas in Her-2/neu transgenic mice, and spontaneous sarcomas in $\mathrm{p} 53^{-/-}$mice [20], however, it was ineffective against BBN-induced bladder carcinogenesis in F344 rats [21]. These results indicate that marine anticancer compounds should be screened in different pre-initiation animal cancer models against several target sites to ensure the optimum efficacy prior to the human clinical trials.

Despite the facts, there were several marine compounds with anticancer potential observed in the in vitro tests and tumor xenograft models entered into the human clinical trials without being thoroughly investigated in the preclinical animal models for their anticancer potentials using diverse biological endpoint biomarkers $[22,23,24$, $25,26,27,28,29,30,31,32]$. Ultimately, some of them were prematurely withdrawn from the clinical trials due to life-threatening toxic side effects in the patients. 
TABLe 1. Antitumor marine natural compounds in clinical trials with preclinical toxicity evaluation in animals.

\begin{tabular}{|c|c|c|c|}
\hline Compound & Phase of clinical trails & Animal model & Toxicities \\
\hline Bryostatin-1 & II & Mice & $\begin{array}{l}\text { In mice, toxicities include lethargy, unsteadiness, } \\
\text { haematuria, and myelosuppression [8]. }\end{array}$ \\
\hline Dolastatin-10 & II & $\begin{array}{l}\text { Mice, rats, } \\
\text { dogs }\end{array}$ & $\begin{array}{l}\text { Maximum tolerated doses of } 1350 \mu \mathrm{g} / \mathrm{m}^{2} \text { (mice), } \\
450 \mu \mathrm{g} / \mathrm{m}^{2} \text { (rats), and } \sim 400 \mu \mathrm{g} / \mathrm{m}^{2}(\text { dogs); Myelotoxicity } \\
\text { was the most severe dose-limiting effect [9]. }\end{array}$ \\
\hline LU103793 ${ }^{a}$ & II & $\mathrm{N} / \mathrm{A}$ & $\begin{array}{l}\text { Toxic effects in hematopoietic, lymphoid } \\
\text { systems, gastrointestinal tract, and heart [8]. }\end{array}$ \\
\hline Discodermolide $^{\mathrm{a}}$ & I & Mice & Immunosuppresive [10]. \\
\hline Yondelis & II/III & $\begin{array}{l}\text { Mice, rats, } \\
\text { monkeys }\end{array}$ & $\begin{array}{l}\text { Reversible hepatobiliary toxicity in monkeys [11]. } \\
\text { Hematotoxic at MTD } 600 \mu \mathrm{g} / \mathrm{m}^{2} \text { in mice [12]. } \\
\text { Hepatotoxic in rats [13]. }\end{array}$ \\
\hline Squalamine & II & Monkeys & $\begin{array}{l}\text { Systemic squalamine injection inhibited the } \\
\text { development of iris neovascularization and caused partial } \\
\text { regression of new vessels in a primate model [14] }\end{array}$ \\
\hline Kahalalide F & I & Rats & $\begin{array}{l}\text { MTD is } 1800 \mu \mathrm{g} / \mathrm{m}^{2} \text {; no-adverse-effect dose } \\
\text { is } 480 \mu \mathrm{g} / \mathrm{m}^{2} / \text { day; nephrotoxic and neurotoxic [15]. }\end{array}$ \\
\hline Aplidin & II & Mice & More toxic effects with prolonged exposure [8]. \\
\hline KRN7000 $^{\mathrm{b}}$ & $\mathrm{I}$ & N/A & N/A $[4,8]$ \\
\hline Cryptophycin-52 & II & N/A & N/A [8] \\
\hline Epothilone B & II & N/A & N/A [16] \\
\hline LAF389 & I & N/A & N/A $[4,16]$ \\
\hline ILX651 $^{\mathrm{a}}$ & I & N/A & N/A [4] \\
\hline HTI286 & I & N/A & N/A $[4,17]$ \\
\hline
\end{tabular}

N/A = not available.

a Dolastatin-15 analogue.

b Agelasphin analouge (alpha-galactosylceramide).

${ }^{c}$ Bengamide B analouge.

One of the most promising marine compounds made to the human clinical trials was didemnin B, a cyclic peptide isolated from the Caribbean tunicate Trididemnum solidum with antiviral and immunosuppressive activity [22]. It was one of the very first marine compounds entered into the human clinical trials conducted simultaneously by several groups for treatment of various cancers $[6,23]$. It has shown ineffectiveness to moderate anticancer response in different target sites and always invariably accompanied with high toxicity to the patients $[24,25,26,27,28,29]$. However, ultimately due to its extreme toxicity, it was withdrawn from the phase II clinical trials $[1,4,6]$. Recent literature search on the MEDLINE for didemnin B resulted in 102 publications in the peer-reviewed journals without finding a single study on the preclinical anticancer evaluation of didemnin B in pre-initiation animal carcinogenesis models. However, the agent demonstrated antitumor activity against a variety of tumor xenograft models $[6,8]$. Animal toxicities in CD2F1 mice, F344 rats, and beagle dogs were also reported in lymphoid system, gastrointestinal tract, liver, and kidney [8]. Further, dehydrodidemnin B or aplidin, an oxidation analog of didemnin B, isolated from Mediterranean tunicate Aplidium albicans with presumably more potent anticancer potential is also being developed for its phase I clinical trials in Europe [3, 30]. However, without proper preclinical evaluation for this compound, it may also meet the same fate as didemnin B.

Similarly, girolline and jaspamide, isolated from the sponge Pseudoaxyssa cantharella [31] and the Indo-Pacific sponge Jaspis splendus [32], respectively, were also withdrawn from the clinical trials due to their extremely toxic side effects. Girolline resulted in hypertension problems in the patients while jaspamide was withdrawn gracefully from the preclinical evaluation stage because it was too toxic [5]. Literature search on both of these compounds resulted in 115 published reports for jaspamide but none were found for girolline. Out of 115 published articles for jaspamide, no report on its toxicity or anticancer potential in the rodent models was found.

Yondelis, a promising anticancer compound, is currently in phase II and phase III clinical trials and has 
been approved as an Orphan Drug [4]. However, substantial hepato- and hemato-toxicities of Yondelis in rats, mice, and monkeys could actually limit its potential use in the human cancer treatment (Table 1) [11, 12, 13]. However, recent study showed that high dose of dexamethasone offered complete protection against the hepatotoxicity in rats by yondelis [13]. Another anticancer compound, LU103793, a dolastatin 15 analogue, has failed to show activity in patients with melanoma and breast cancer in phase II trials, however, trials are ongoing in ovarian, prostate, and colon cancer patients [33, 34]. Besides their therapeutic efficacy studies in tumor xenograft models, these compounds along with many others have not been evaluated for their anticancer potentials in the chemical/oncogene-induced animal carcinogenesis models.

\section{IMPORTANCE OF BIOMARKERS}

Genotoxic and anticancer profiles for the majority of the marine compounds currently in the clinical trials are scarcely available. A few reports appeared regarding the genotoxicity of marine compounds in vitro. Most of them employed relatively nonspecific and superficial assays (eg, Ames Salmonella, SOS induction, micronuclei, sister chromatid exchange, and mutatox) for measuring genotoxic potential $[35,36]$. Further, the majority of the articles published so far have considered the cytotoxicity, apoptosis, and/or cell proliferation assays as benchmark screening tools/markers for assessing the anticancer potential of a compound. However, the majority of biomarkers currently in use have not been rigorously validated [37]. Thus far, there is no one universal biomarker for malignant neoplastic diseases. It is therefore possible that more than one biomarker, for example, DNA adducts, gene expression, and DNA repair activity may need to be considered for assuring the anticancer potential of a compound.

Central dogma of carcinogenesis involves multiple steps of initiation, promotion, and progression which simultaneously also provides numerous opportunities for chemoprevention and/or therapeutic strategies. One of the widely accepted notions is that the covalent DNA adduct formation represents a prerequisite step in the process of cancer initiation. Further, DNA adducts represent the net balance between the metabolism, detoxification, and to certain extent the DNA repair and therefore have been considered as an excellent intermediary biological marker to study the genotoxic and anticancer potentials of compounds $[38,39,40,41,42,43,44,45,46,47,48$, $49,50,51,52,53]$.

The applicability of DNA adducts as early biomarkers in carcinogenesis and cancer prevention studies is supported by several facts: (i) carcinogen-DNA adduct formation, their presence and levels in animals and humans correlate with carcinogen exposure (reviewed in $[39,40])$; (ii) the presence of DNA adducts in humans has been associated with an increased risk for cancer development [41]; (iii) the adduct forming capacity, mutagenic and carcinogenic potentials correlate for many carcinogens $[42,43,44]$; (iv) the inhibition of carcinogeninduced DNA adducts both in vitro and in vivo generally classifies a compound to be a probable anticancer $[45,46,47,48,49,50]$; and (v) inhibition of DNA adducts by chemopreventive agents has been correlated with decreased tumorigenesis in animals $[51,52,53]$.

Despite the fact that several marine anticancer compounds are considered to be DNA-interactive, causing from reductive DNA cleavage [54] to DNA adduct formation [55], not much attention has been given to the DNA adduct as early biomarker in the development of marine anticancer drugs. In our continuous effort to search for new potential anticancer compounds, we have screened few marine compounds for their genotoxic and chemopreventive potentials using benzo[a]pyrene (BP)-derived DNA adducts as endpoint biomarker in MCF-7 cells as described by Smith et al [47]. These new marine compounds, for example, manzamine A, sarcophine, curcudiol, curcuphenol, aaptamine, and verongiaquinol were reported in the literature with antimalarial, antiviral, and antitumor activities [56, 57, 58, 59, 60, 61, 62, 63, 64]. Manzamine A and sarcophine were reported to have anticancer activity $[56,59,64]$. Sarcophine, a furanocembrane diterpene, isolated from the Red Sea soft coral Sarcophyton glaucum, was found to serve as an effective inhibitor of JB6 cell transformation [59]. A substantial increase (up to $400 \%$ ) was noticed in the BP diol epoxide-DNA adduct formation in the MCF-7 cells by nearly all the compounds (Arif, Kunhi, Siddiqui, El-Sayed, Orabi, Al-Hazzani, AlAhdal, Al-Khodairy, manuscript in preparation). Interestingly, sarcophine $(100 \mu \mathrm{M})$ and manzamine $\mathrm{A}(50 \mu \mathrm{M})$, the probable anticancer compounds, were of the significant inducers of BP-DNA adduct formation. These marine compounds themselves did not actually form any lipophilic DNA adducts, however, they modulated the DNA adduct formation by BP suggesting that they could enhance the DNA adduction in the animal and/or human tissues which could be preexposed to different carcinogens via diet and environment. Though the mechanism(s) of increased BP-DNA adduct formation by these compounds is not known, it could be due to modulation in the metabolic activation (phase I enzymes), detoxification (phase II enzymes) and/or DNA repair. Based on the preliminary data, sarcophine and manzamine A may be considered as probable genotoxic rather than anticancer compounds and they should be cross-examined using additional biomarkers prior to be tested in the animal models and human clinical trials. This being the first observation with the marine compounds using DNA adducts as intermediary biomarker further stresses the importance of DNA adducts in assuring the anticancer potential of new compounds. Further studies on DNA repair and related genes with marine compounds are in progress in our laboratory. 


\section{CONCLUSIONS}

In the past several decades, thousands of marine compounds with tremendous pharmacological activities have been isolated and more than a dozen of them are in different stages of human clinical trials against various diseases. However, several of the known marine compounds were also withdrawn prematurely from clinical trials because of their extremely toxic side effects. Most of these anticancer marine compounds currently in clinical trials utilize their therapeutic potentials were tested in short-term animal studies using human tumor xenografts, however, only two compounds (Cytarabine and KRN7000) were tested in chemical- and/or oncogene-induced pre-initiation animal carcinogenesis models for their anticancer potentials.

In summary, it is the time to carefully and thoroughly screen any marine compound for anticancer and genotoxic potentials using variety of biomarkers in animal carcinogenesis models prior to their entry into the clinical trials, otherwise, there may be no surprise that they could also meet similar fate as didemnin B and others with substantial setback to the marine drug development programs.

\section{ACKNOWLEDGMENTS}

The authors would like to thank the Research Center Administration for their continuous support and encouragement. We also would like to thank Drs. K. A. El-Sayed (USA) and K. Y. Orabi (Kuwait) for their collaborations on anticancer potential studies with the selected marine compounds.

\section{REFERENCES}

[1] Proksch P, Edrada RA, Ebel R. Drugs from the seas-current status and microbiological implications. Appl Microbiol Biotechnol. 2002;59(2-3):125134.

[2] Mayer AM, Gustafson KR. Marine pharmacology in 2000: antitumor and cytotoxic compounds. Int J Cancer. 2003;105(3):291-299.

[3] Garcia-Fernandez LF, Reyes F, Sanchez-Puelles JM. The marine pharmacy: new antitumoral compounds from the sea. Pharmaceut News. 2002;9:495-501.

[4] Haefner B. Drugs from the deep: marine natural products as drug candidates. Drug Discov Today. 2003;8(12):536-544.

[5] Faulkner DJ. Marine pharmacology. Antonie Van Leeuwenhoek. 2000;77(2):135-145.

[6] Amador ML, Jimeno J, Paz-Ares L, Cortes-Funes H, Hidalgo M. Progress in the development and acquisition of anticancer agents from marine sources. Ann Oncol. 2003;14(11):1607-1615.

[7] Mayer AM, Lehmann VK. Marine pharmacology in 1999: antitumor and cytotoxic compounds. Anticancer Res. 2001;21(4A):2489-2500.
[8] Schwartsmann G, Da Rocha AB, Mattei J, Lopes R. Marine-derived anticancer agents in clinical trials. Expert Opin Investig Drugs. 2003;12(8):1367-1383.

[9] Mirsalis JC, Schindler-Horvat J, Hill JR, Tomaszewski JE, Donohue SJ, Tyson CA. Toxicity of dolastatin 10 in mice, rats and dogs and its clinical relevance. Cancer Chemother Pharmacol. 1999;44(5): 395-402.

[10] Longley RE, Caddigan D, Harmody D, Gunasekera M, Gunasekera SP. Discodermolide-a new, marinederived immunosuppressive compound. II. In vivo studies Transplantation. 1991;52(4):656-661.

[11] D'Incalci M, Jimeno J. Preclinical and clinical results with the natural marine product ET-743. Expert Opin Investig Drugs. 2003;12(11):1843-1853.

[12] Gomez SG, Bueren JA, Faircloth G, Albella B. Use of CFU-GM assay for prediction of human maximum tolerated dose of a new antitumoral drug: Yondelis (ET-743). Toxicol In Vitro. 2003;17(5-6):671-674.

[13] Donald S, Verschoyle RD, Greaves P, et al. Complete protection by high-dose dexamethasone against the hepatotoxicity of the novel antitumor drug yondelis (ET-743) in the rat. Cancer Res. 2003;63(18):59025908.

[14] Genaidy M, Kazi AA, Peyman GA, et al. Effect of squalamine on iris neovascularization in monkeys. Retina. 2002;22(6):772-778.

[15] Brown AP, Morrissey RL, Faircloth GT, Levine BS. Preclinical toxicity studies of kahalalide F, a new anticancer agent: single and multiple dosing regimens in the rat. Cancer Chemother Pharmacol. 2002;50(4):333-340.

[16] Wu J-H, Morris-Natschke SL, Lee K-H. Progress in the recent discovery and development of promising anticancer and anti-HIV agents from natural products in the United States. J Chinese Chem Soc. 2003;50:11-22.

[17] Loganzo F, Discafani CM, Annable T, et al. HTI-286, a synthetic analogue of the tripeptide hemiasterlin, is a potent antimicrotubule agent that circumvents P-glycoprotein-mediated resistance in vitro and in vivo. Cancer Res. 2003;63(8):1838-1845.

[18] Donia M, Hamann MT. Marine natural products and their potential applications as anti-infective agents. Lancet Infect Dis. 2003;3(6):338-348.

[19] Okamura T. Effect of intrabladder instillation of various anticancer agents on carcinogenesis in rat bladder. Hinyokika Kiyo. 1988;34(11):1895-1902.

[20] Hayakawa Y, Rovero S, Forni G, Smyth MJ. Alpha-galactosylceramide (KRN7000) suppression of chemical- and oncogene-dependent carcinogenesis. Proc Natl Acad Sci USA. 2003;100(16):94649469.

[21] Mitsuhashi M, Wanibuchi H, Wei M, et al. No inhibition of urinary bladder carcinogenesis in rats with intravesical instillation of alpha-galactosylceramide. Asian Pac J Cancer Prev. 2003;4(1):45-50. 
[22] Vera MD, Joullie MM. Natural products as probes of cell biology: 20 years of didemnin research. Med Res Rev. 2002;22:102-145.

[23] Rinehart KL Jr, Gloer JB, Hughes RG Jr, et al. Didemnins: antiviral and antitumor depsipeptides from a caribbean tunicate. Science. 1981; 212(4497): 933-935.

[24] Grubb DR, Wolvetang EJ, Lawen A. Didemnin B induces cell death by apoptosis: the fastest induction of apoptosis ever described. Biochem Biophys Res Commun. 1995;215(3):1130-1136.

[25] Malfetano JH, Blessing JA, Homesley HD, Look KY, McGehee R. A phase II trial of didemnin B (NSC \#335319) in patients with advanced squamous cell carcinoma of the cervix. A Gynecologic Oncology Group Study. Am J Clin Oncol. 1996;19(2): 184-186.

[26] Taylor SA, Giroux DJ, Jaeckle KA, Panella TJ, Dakhil SR, Schold SC. Phase II study of didemnin B in central nervous system tumors: a Southwest Oncology Group Study. Invest New Drugs. 1998-99;16(4):331332.

[27] Geldof AA, Mastbergen SC, Henrar RE, Faircloth GT. Cytotoxicity and neurocytotoxicity of new marine anticancer agents evaluated using in vitro assays. Cancer Chemother Pharmacol. 1999;44(4):312-318.

[28] Mittelman A, Chun HG, Puccio C, Coombe N, Lansen T, Ahmed T. Phase II clinical trial of didemnin $\mathrm{B}$ in patients with recurrent or refractory anaplastic astrocytoma or glioblastoma multiforme (NSC 325319). Invest New Drugs. 1999;17(2):179182.

[29] Kucuk O, Young ML, Habermann TM, Wolf BC, Jimeno J, Cassileth PA. Phase II trail of didemnin $\mathrm{B}$ in previously treated non-Hodgkin's lymphoma: an Eastern Cooperative Oncology Group (ECOG) study. Am J Clin Oncol. 2000;23(3):273-277.

[30] Sakai R, Rinehart KL, Kishore V, et al. Structureactivity relationships of the didemnins. J Med Chem. 1996;39(14):2819-2834.

[31] Ahond A, Bedoya Zurita M, Colin M, et al. La girolline, nouvelle substance antitumorale extraite de l'eponge, Pseudaxinyssa cantharella n. sp. (Axinellidae). CR Acad Sci Paris Serie II. 1988;307:145-148.

[32] Crews P, Manes LV, Boehler M. Jasplakinolide, a cyclodepsipeptide from the marine sponge, Jaspis sp. Tetrahedron Lett. 1986;27:2797-2800.

[33] Smyth J, Boneterre ME, Schellens J, et al. Activity of the dolastatin analogue, LU103793, in malignant melanoma. Ann Oncol. 2001;12(4):509-511.

[34] Kerbrat P, Dieras V, Pavlidis N, Ravaud A, Wanders J, Fumoleau P. Phase II study of LU103793 (dolastatin analogue) in patients with metastatic breast cancer. Eur J Cancer. 2003;39(3):317-320.

[35] Leary JV, Kfir R, Sims JJ, Fulbright DW. The mutagenicity of natural products from marine algae. $\mathrm{Mu}$ tat Res. 1979;68(4):301-305.
[36] Arfsten DP, Davenport R, Schaeffer DJ. Reversion of bioluminescent bacteria (Mutatox) to their luminescent state upon exposure to organic compounds, munitions, and metal salts. Biomed Environ Sci. 1994;7(2):144-149.

[37] Greenwald P, Kelloff GJ, Boone CW, McDonald SS. Genetic and cellular changes in colorectal cancer: proposed targets of chemopreventive agents. Cancer Epidemiol Biomarkers Prev. 1995;4(7):691-702.

[38] Arif JM, Gupta RC. Role of DNA adducts in defining bioactivation mechanism(s) of genotoxic compounds. Int J Oncol. 1996;8:681-685.

[39] Beach AC, Gupta RC. Human biomonitoring and the ${ }^{32}$ P-postlabeling assay. Carcinogenesis. 1992; 13(7):1053-1074.

[40] Hemminki K. DNA adducts, mutations and cancer. Carcinogenesis. 1993;14(10):2007-2012.

[41] Santella RM. DNA damage as an intermediate biomarker in intervention studies. Proc Soc Exp Biol Med. 1997;216(2):166-171.

[42] Nesnow S, Ross JA, Stoner GD, Mass MJ. Mechanistic linkage between DNA adducts, mutations in oncogenes and tumorigenesis of carcinogenic environmental polycyclic aromatic hydrocarbons in strain A/J mice. Toxicology. 1995;105(2-3):403-413.

[43] Arif JM, Smith WA, Gupta RC. Tissue distribution of DNA adducts in rats treated by intramammillary injection with dibenzo $[a, l]$ pyrene, 7,12 dimethylbenz $[a]$ anthracene and benzo $[a]$ pyrene. Mutat Res. 1997;378(1-2):31-39.

[44] Hemminki K, Koskinen M, Rajaniemi H, Zhao C. DNA adducts, mutations, and cancer 2000. Regul Toxicol Pharmacol. 2000;32(3):264-275.

[45] Smith WA, Gupta RC. Use of a microsome-mediated test system to assess efficacy and mechanisms of cancer chemopreventive agents. Carcinogenesis. 1996;17(6):1285-1290.

[46] Smith WA, Arif JM, Gupta RC. Effect of cancer chemopreventive agents on microsome-mediated DNA adduction of the breast carcinogen dibenzo[a,l]pyrene. Mutat Res. 1998;412(3):307314.

[47] Smith WA, Freeman JW, Gupta RC. Effect of chemopreventive agents on DNA adduction induced by the potent mammary carcinogen dibenzo $[a, l]$ pyrene in the human breast cells MCF-7. Mutat Res. 2001;480481:97-108.

[48] Smith WA, Arif JM, Gupta RC. 1,2-dithiole-3-thione and its structural analogue oltipraz are potent inhibitors of dibenz. Int J Cancer. 2001;91(1):132-136.

[49] Arif JM, Gairola CG, Glauert HP, Lubet RA, Kelloff GJ, Gupta RC. Inhibition of cigarette smoke-related lipophilic DNA adducts in rat tissues by dietary oltipraz. Carcinogenesis. 1998;19(8):1515-1517.

[50] Arif JM, Gairola CG, Kelloff GJ, Lubet RA, Gupta RC. Inhibition of cigarette smoke-related DNA adducts in rat tissues by indole-3-carbinol. Mutat Res. 2000;452(1):11-18. 
[51] Groopman JD, DeMatos P, Egner PA, Love-Hunt A, Kensler TW. Molecular dosimetry of urinary aflatoxin- $\mathrm{N}^{7}$-guanine and serum aflatoxin-albumin adducts predicts chemoprotection by 1,2-dithiole-3thione in rats. Carcinogenesis. 1992;13(1):101-106.

[52] Egner PA, Gange SJ, Dolan PM, Groopman JD, Munoz A, Kensler TW. Levels of aflatoxin-albumin biomarkers in rat plasma are modulated by both long-term and transient interventions with oltipraz. Carcinogenesis. 1995;16(8):1769-1773.

[53] Devanaboyina U, Gairola CG, Kelloff GJ, Lubet RA, Gupta RC. Effect of indole-3-carbinol (I3C) and phenethylisothiocyanate (PEITC) on 7,12dimethylbenz $[a]$ anthracene (DMBA)-induced DNA adducts in rat mammary glands and liver. Proc Am Assoc Cancer Res. 1997;38:362.

[54] Matsumoto SS, Sidford MH, Holden JA, Barrows LR, Copp BR. Mechanism of action studies of cytotoxic marine alkaloids: ascididemin exhibits thioldependent oxidative DNA cleavage. Tetrahedron Lett. 2000;41:1667-1670.

[55] Aune GJ, Furuta T, Pommier Y. Ecteinascidin 743: a novel anticancer drug with a unique mechanism of action. Anticancer Drugs. 2002;13(6):545-555.

[56] Pandit UK. Strategies for the synthesis of some complex antitumor alkaloids. Farmaco. 1995;50(11): 749-754.

[57] Carney JR, Rinehart KL. Biosynthesis of brominated tyrosine metabolites by Aplysina fistularis. J Nat Prod. 1995;58(7):971-985.

[58] Edrada RA, Proksch P, Wray V, Witte L, Muller WE, Van Soest RW. Four new bioactive manzaminetype alkaloids from the Philippine marine sponge Xestospongia ashmorica. J Nat Prod. 1996;59(11): 1056-1060.

[59] El Sayed KA, Hamann MT, Waddling CA, et al. Structurally novel bioconversion products of the marine natural product sarcophine effectively inhibit JB6 cell transformation. J Org Chem. 1998; 63(21):7449-7455.

[60] El Sayed KA, Kelly M, Kara UA, et al. New manzamine alkaloids with potent activity against infectious diseases. J Am Chem Soc. 2001;123(9):1804-1808.

[61] El Sayed KA, Yousaf M, Hamann MT, Avery MA, Kelly M, Wipf P. Microbial and chemical transformation studies of the bioactive marine sesquiterpenes (S)-(+)-curcuphenol and -curcudiol isolated from a deep reef collection of the jamaican sponge Didiscus oxeata. J Nat Prod. 2002;65(11):1547-1553.

[62] Shen YC, Lin TT, Sheu JH, Duh CY. Structures and cytotoxicity relationship of isoaaptamine and aaptamine derivatives. J Nat Prod. 1999;62(9):12641267.

[63] D’Armas HT, Mootoo BS, Reynolds WF. An unusual sesquiterpene derivative from the Caribbean gorgonian Pseudopterogorgia rigida. J Nat Prod. 2000;63(11):1593-1595.
[64] Ichiba T, Corgiat JM, Scheuer PJ, Kelly-Borges M. 8-Hydroxymanzamine A, a beta-carboline alkaloid from a sponge, Pachypellina sp. J Nat Prod. 1994;57(1):168-170.

* Corresponding author.

E-mail: jarif@kfshrc.edu.sa

Fax: +9661442 7858; Tel: +96614647272 

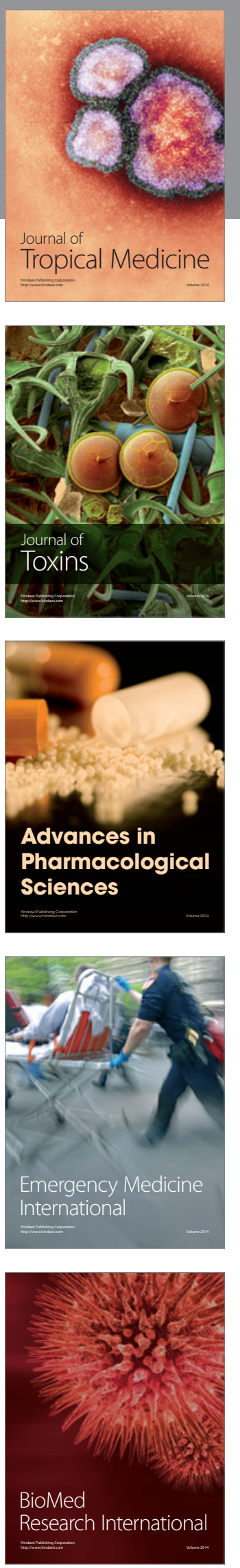
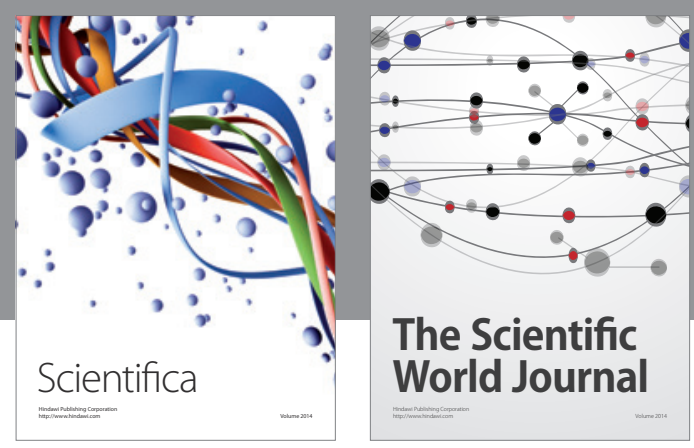

The Scientific World Journal
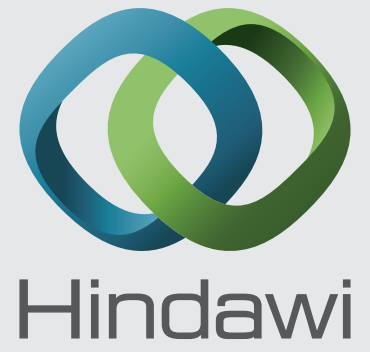

Submit your manuscripts at

http://www.hindawi.com
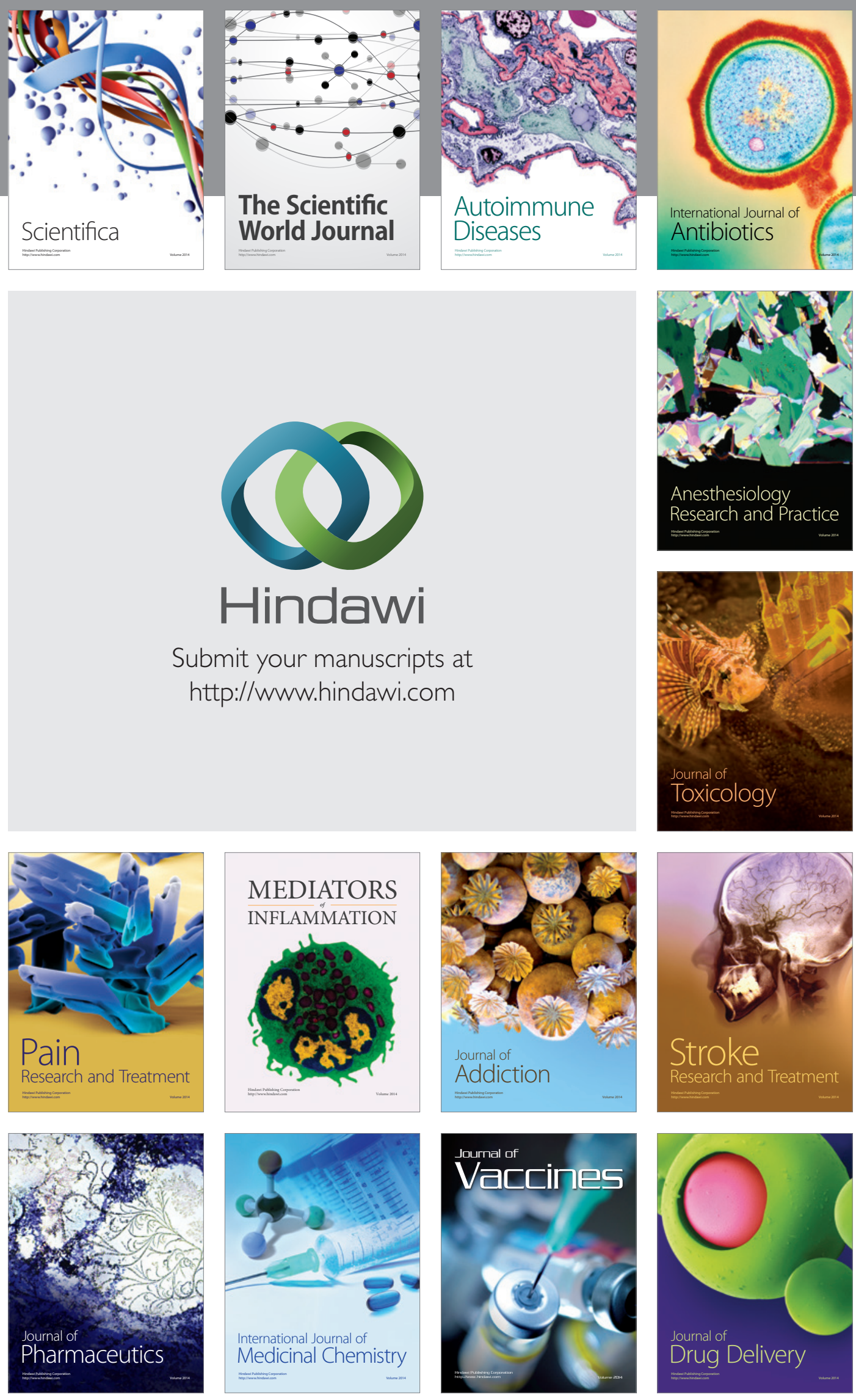